\title{
Synthesis and preliminary pharmacological evaluation of aminobenzensulfonamides derivatives of diflunisal as a anti-inflammatory agents
}

\author{
Munther F. mahdi, ${ }^{*}$ Abdul-Rassoul Wars, ${ }^{*}$ Samira Fingan** \\ * Department of pharmaceutical chemistry, **Department of pharmacology and toxicology, college of \\ pharmacy, university of Baghdad.
}

\begin{abstract}
Objective: Synthesized of amino derivatives [\{-aminobenzenesulfonamide, -amino-Nmethylbenzenesulfonamide, or $\mathrm{N}$-(\{-aminophenylsulfonyl) acetamide] bound to carboxyl group of diflunisal, a well known nonsteroidal anti-inflammatory drugs (NSAIDs). and evaluation as a potential anti-inflammatory agent with expected selectivity against COX-r enzyme.

Design: Expermental study

Results: In vivo acute anti-inflammatory activity of the final compounds $(1 r, 1 \leqslant \& 10)$ was evaluated in rat using egg-white induced edema model of inflammation in a dose equivalent to $(0 \cdot \mathrm{mg} / \mathrm{Kg})$ of diflunisal. All tested compounds produced significant reduction of paw edema with respect to the effect of propylene glycol $0 . \% \mathrm{v} / \mathrm{v}$ (control group). Moreover, compound ( $(\varepsilon)$ exhibited comparable anti-inflammatory activity to diclofenac $(r \mathrm{mg} / \mathrm{Kg})$, while compound $(1 r)$ showed short duration of action, and compound (10) exhibited comparable effect to that of diclofenac with slower onset of action.

Conclusion:The result of this study indicate that the incorporation of the \&-aminobenzenesulfonamide pharamacophore \& its derivatives into diflunisal enhanced its anti-inflammatory activity\& may increased its selectivity toward COX-r enzyme which can be confirmed in future by assessing COX$r$ :COX-l inhibitory ratio using whole blood assay.
\end{abstract}

\section{الخلاصة}

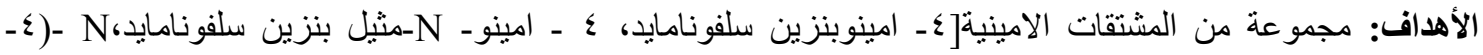

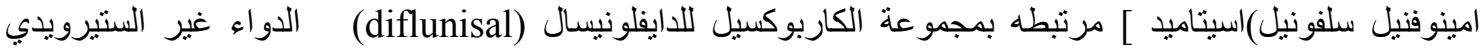

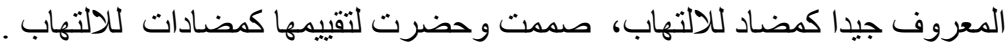
التصميم: در اسة مخبرية

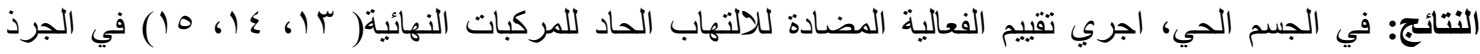

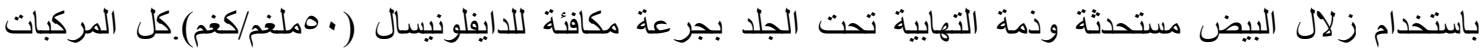

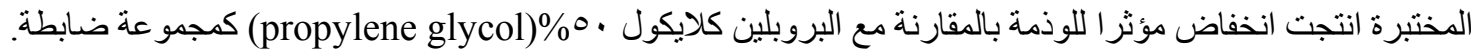

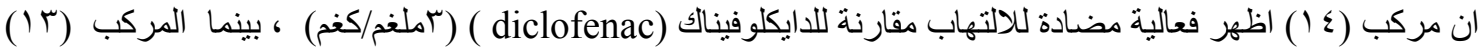
اظهر فعالية استمرارية اقصر و المركب (10) اظهر فعالية مضادة للالتهاب مقارنة للايكلوفيناك مع فعالية ابتدائية

الاستنتاج: نتيجة هذه الدراسة تثشير الى ان اندماج الجزء العقاقيري ع ــ امينوبنزين سلفونامايد ومشتقاته مع الدايفلونيسال

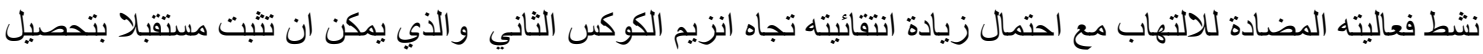

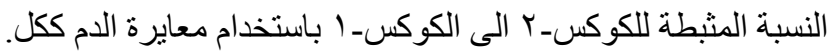


T $\mathrm{n}$ ।^९9, acetyl salicylic acid (aspirin, I) was

introduced as the first potent drug to treat rheumatic disease. In the following decades, dozen of non-steroidal anti-inflammatory drugs (NSAIDs) were developed and launched, but the first real progress in our understanding of the mechanism of action of the NSAIDs came in I9VI when Vane revealed that these chemically varied drugs all reduced the formation of prostaglandins (PG). This ability was associated with inhibition of cyclooxygenase (COX) enzyme.'

Cyclooxygenase is a rate limiting enzyme for prostaglandin synthesis. 'The three isoenzymes of COX (COX-), COX-r and COX$r$ ) have been identified $r$, s though COX-r activity in human has not been confirmed ${ }^{\circ}$ COX-1 is constitutively expressed, widely distributed and has "housekeeping" function. It is of particular importance in maintaining gastric mucosal integrity, renal function and homeostasis.' COX-r is highly induced in settings of inflammation by cytokines and inflammatory mediators or physiological stress.

$r, \wedge$ However, COX-r also is constitutively expressed in certain areas of kidney, brain, reproductive tract, " the vascular system, '. in wound healing, lung and bone."

\section{compound 7 ( $\{$-amino-N-methylbenzenesulfonamide)}

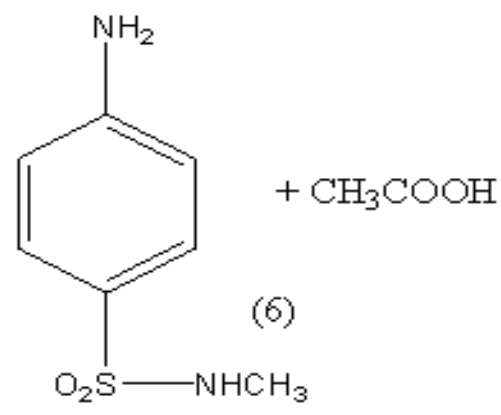

The search for a clinical replacement for aspirin resulted in the development of the nonacetylating salicylic acid derivative diflunisal (II) that is a more potent antiinflammatory and analgesic agent with a longer duration of action that is less ulcerogenic than aspirin. $^{~}{ }^{r}$

However, since the identification of cyclooxygenase-r (COX-r), the field of inflammation and particularly the search for effective NSAIDs with fewer adverse effects has greatly intensified. Increasing number of experimental and clinical data support the role of selective COX-r inhibitor in antiinflammatory processes and the involvement of COX-1 inhibition in the side effects associated with using NSAIDs. '" Many of the selective COX-r inhibitors containing benzenesulfonamide derivative, like valdecoxib (III), 's ,celecoxib (IV), ${ }^{10}$ or benzene-N-methyl sulfonamide like compound (V). ${ }^{17}$

In a recent study, it was shown that the incorporation of a para-N-acetylsulfonamido substitute on the $\mathrm{C}-\mathrm{r}$ phenyl ring of the rofecoxib (VI) regioisomer provided a highly potent and selective COX-r inhibitor that has the potential to acetylate the COX-r isoenzyme. 'Y

compound $\varepsilon$

( $\{$-aminobenzenesulfonamide)

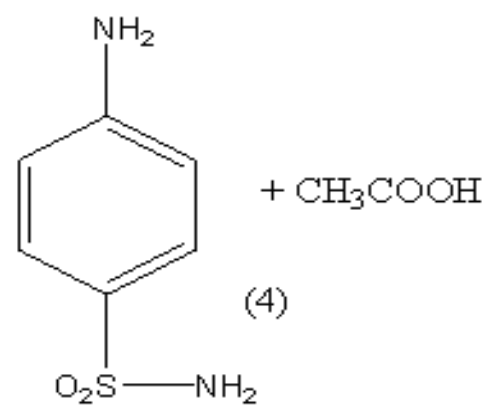


<smiles>CC(=O)Oc1ccccc1C(=O)O</smiles><smiles>Cc1ccc(-c2cc(C(F)(F)F)nn2-c2ccc(S(N)(=O)=O)cc2)cc1</smiles>

IV<smiles>O=C(O)c1cc(-c2ccc(F)cc2F)ccc1O</smiles>

II<smiles>COc1cc2c(cc1Cc1ccccc1)OCO2</smiles>

V<smiles>Cc1onc(-c2ccccc2)c1-c1ccc(S(N)(=O)=O)cc1</smiles>

III
In the view of this background, the present study was conducted to design, synthesize and preliminarily evaluate new diflunisal derivatives as potential NSAIDs and future study to measure their selectivity's on COX-r enzyme.

\section{Chemistry}

The general routes outlined in schemes 1 and $r$ were used to synthesize all compounds described here.

As shown in scheme 1; \&-aminobenzene-

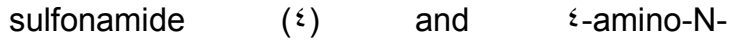
methylbenzenesulfonamide ( 7 ) were prepared as described previously (Vogel) ${ }^{(\wedge)}$ starting from acetanilide.

\section{2}

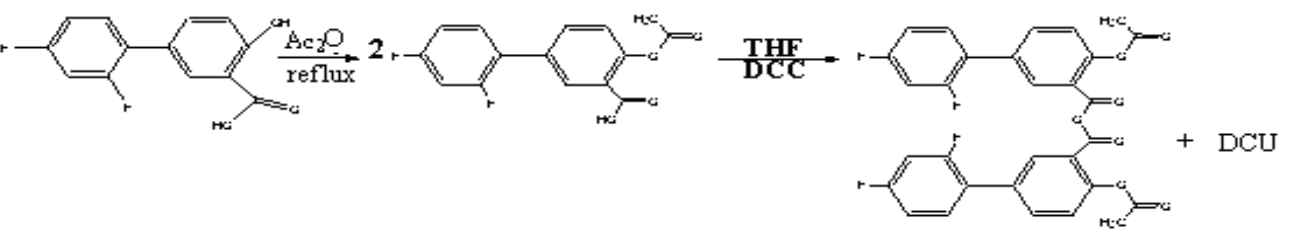

(7)

(8)

(9)

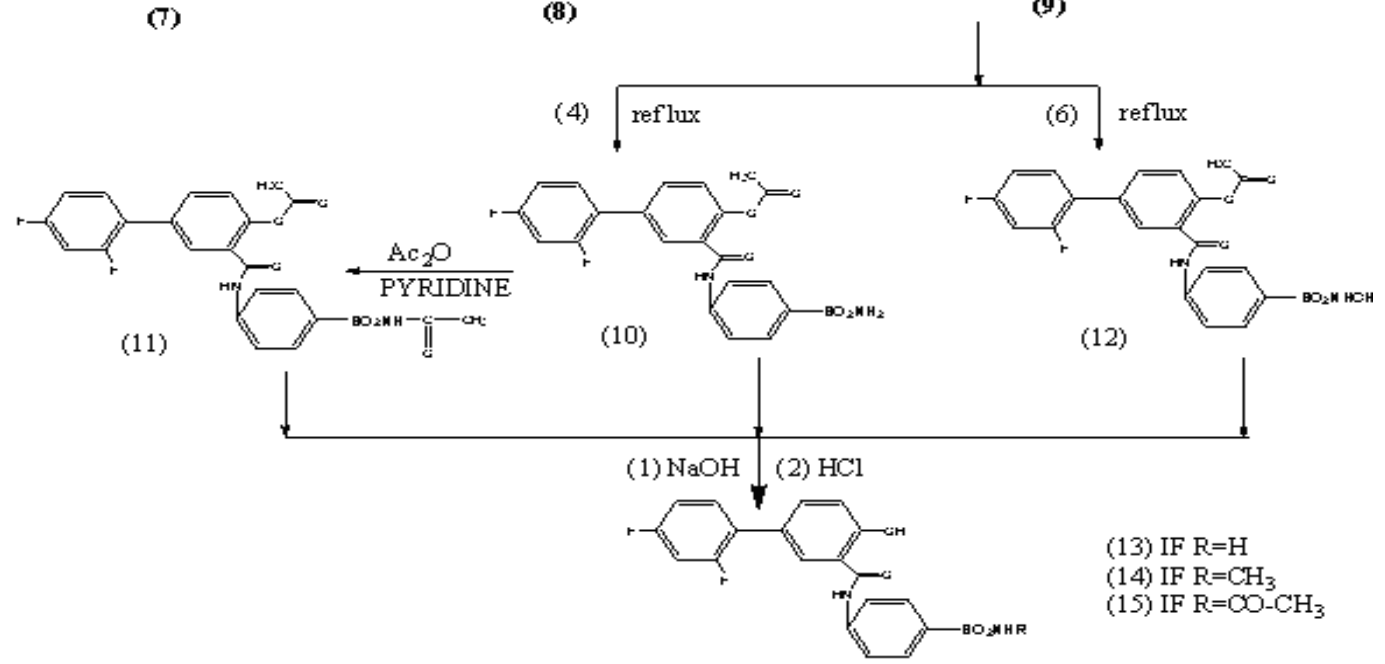

Schemel :Synthesis of compounds 13,14and 15 


\section{Experimental}

All reagents and anhydrous solvents were of analar type and generally used as received from the commercial supplier (Merk_Germany,ReidelDehean_Germany ,Sigma-Aldrich_Germany \&BDH_England).Diflunisal was supplied from RAM Company _ Jordan.

Melting points were determined by capillary method on Thomas Hoover apparatus (England) and ascending thin layer chromatography (TLC) was run on DC-Kartan SI Alumina $\cdot r \mathrm{~mm}$ to check the purity and progress of reaction. The identification of compounds was done using iodine vapour and the chromatograms were eluted by: Methanol: Acetic acid: Ether:

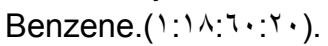

IR spectra were recorded on model 0. . scientific IR spectrophotometer, Buck Company (USA) as a $\mathrm{KBr}$ film. $\mathrm{CHN}$ microanalysis was done by using Carlo Erba elemental analyzer $11 \cdot 7$, Italy. r.) Synthesis of $\varepsilon$-acetoxy- $r^{\prime}$, $\Sigma^{\prime}$-diflourobiphenyl-r. carboxylic acid $(\wedge) .^{19}$

In a ro.ml conical flask, equipped with reflux condenser, diflunisal $(\vee)(\circ \mathrm{g}, r \cdot \mathrm{mmol})$ and acetic anhydride $(10 \mathrm{ml}, 109 \mathrm{mmol})$ were placed and $r$ drops of concentrated sulfuric acid were added dropwise. The reaction mixture was refluxed gently for I hour, and then allowed to cool with occasional stirring. Cold ice-water was then added until precipitate was formed, filtered by using sucking pump, washed by cold distill water several times, the crude product was collected. The recrystallization was carried out by using ethanol $90 \%$, the precipitate was collected and dried to give compound $\wedge^{(19)}(0 . \mathrm{rg}, 91 \%$ yield $)$ as white crystal. m.p. $1 \vee 1-1 \vee r{ }^{\circ} \mathrm{C} . \mathrm{R}_{\mathrm{f}}=\cdot . \wedge 9 . \mathrm{IR} \mathrm{cm}^{-1}$ $\operatorname{\vee \wedge } \wedge(C=O)$ of acetate ester, $\quad \vee \cdots(C=O)$ of carboxylic acid, $171 \mathrm{~V}, 1094 \& 1 \leqslant \wedge \wedge$ (Aromatic) $\mathrm{cm}^{-1}$. $r$ r Synthesis of $\varepsilon$-acetoxy- $r^{\prime}$, $\varepsilon^{\prime}$-diflourobiphenyl$r$-carboxylic anhydride ( $\left.{ }^{9}\right)$

Compound $\wedge\left({ }^{\circ} \mathrm{g}, 1 \vee .1 \mathrm{mmol}\right)$ was dissolved in THF $(r \cdot \mathrm{ml})$, and then Di-Cyclohexyl Carbodiamide (DCC) ( $1 . \vee \circ \mathrm{g}, 1.00 \mathrm{mmol})$ was added. The reaction mixture was continuously stirred at room temperature for $\varepsilon$ hours. A white precipitate of di-Cyclohexyl Urea (DCU) was formed which then removed by filtration. The solvent was evaporated under vacuum to give $q^{(r \cdot)},(\leqslant g, \wedge r \%$ yield) as a white powder. m.p.

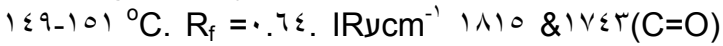
of anhydride, $17 \mathrm{rr}, 101 \wedge \& 1 \leqslant \wedge \wedge$ (Aromatic), I $\mathrm{rVV}$, IrIO\& IVT[C - $(\mathrm{C}=\mathrm{O})-\mathrm{O}-(\mathrm{C}=\mathrm{O})-\mathrm{C}] \mathrm{cm}^{-1}$ of anhydride.r.r Synthesis of $r^{\prime}$, $\varepsilon^{\prime}$-diflouro-r-( $\varepsilon_{-}$ sulfamoylphenylcarbamoyl) biphenyl - - -yl acetate $(1 \cdot)^{(r)}$

Compound q (r.)g, r.rmmol), compound $\varepsilon$ $(\cdot . \imath \mathrm{g}, r . \vee \mathrm{mmol})$, zinc dust $(\varepsilon \mathrm{mg})$, glacial acetic acid $(\cdot r \circ \mathrm{ml}, \tau .1 r \mathrm{mmol})$ and dioxane $(r \cdot \mathrm{ml})$ were placed in a flask, equipped with reflux condenser. The reaction mixture was refluxed gently for $q$. minutes. The solvent was evaporated under vacuum, the residue was dissolved in ethylacetate, washed with $\mathrm{NaHCO}_{r}(1 . \%), \mathrm{HCl}$ ( $\mathrm{N}$ ) and distilled water (three times for each step), filtered over anhydrous magnesium sulfate. The filtrate was evaporated under vacuum to give compound $1 \cdot$. Recrystallization was carried out by dissolving the compound in ethyl acetate, petroleum ether $\left(\wedge \cdot-1 \cdots{ }^{\circ} \mathrm{C}\right)$ was then added on the filtrate until turbidity took place and it was kept in cold place over night. The mixture was filtered while cold and the precipitate was collected to give compound $1 \cdot,\left(\cdot .{ }^{\top} \mathrm{g}, \uparrow т \%\right.$ yield $)$ as white crystals. m.p. $r|r-r| r^{\circ} \mathrm{C} . \mathrm{R}_{\mathrm{f}}=\cdot . \wedge \mathrm{v}$. IRעcm ${ }^{-1}$ rror\&rroq $(\mathrm{N}-\mathrm{H})$ of primary sulfonamide

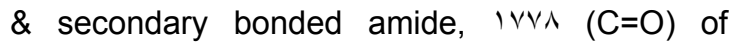
acetate ester, $17 \mathrm{~V} \cdot(\mathrm{C}=\mathrm{O})$ of secondary amide, 109r, lorv\&l \&10(Aromatic), $1419 \& 1171$ (SOr) $\mathrm{cm}^{-1} r$. $\varepsilon$ Synthesis of $r-(\varepsilon-(\mathrm{N}$-acetylsulfamoyl) phenylcarbamoyl) - $r^{\prime}, \quad \varepsilon '$-diflouro biphenyl- $\varepsilon-y l$ acetate (11)

Acetic anhydride $(\cdot .7 \mathrm{ml}$, $7 \mathrm{mmol})$, was added to a solution of compound $1 \cdot(\cdot . \wedge \mathrm{g}, r \mathrm{mmol})$ in pyridine $(l \cdot \mathrm{ml})$ and the reaction was allowed to proceed at $r 0{ }^{\circ} \mathrm{C}$ with stirring for 7 hours. Ethyl acetate $(1 \cdots \mathrm{ml})$ was added and this solution was washed successively with saturated aqueous ammonium chloride $(r \times r \cdot \mathrm{ml})$ and distilled water $\left({ }^{r} \times r \cdot m l\right)$. The organic fraction was dried with anhydrous magnesium sulfate and the solvent was removed in vacuum to give $)^{(r)},(\cdot \varepsilon \vee \mathrm{V}$,

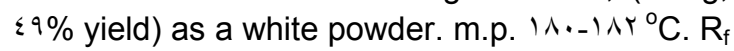
$=\cdot . \vee \wedge \cdot \mathrm{IRcm}^{-1} \mathrm{r} \cdot \varepsilon \& r r r v(\mathrm{~N}-\mathrm{H})$ of secondary amide \&sulfonamide, ivor $(\mathrm{C}=\mathrm{O})$ of acetate ester, 17\%. ( $\mathrm{C}=\mathrm{O})$ of secondary amide, $1091 \&$ lor. $(\mathrm{C}=\mathrm{c})$ \& Irrv \& $1 \mathrm{rov}(\mathrm{SOr})$ asymmetric and symmetric., respectively . r.o Synthesis of $r^{\prime}, \Sigma^{\prime}-$ diflouro-r-( $\varepsilon_{-}(\mathrm{N}-$

methylsulfamoyl)phenylcarbamoyl) biphenyl- $\varepsilon-y l$ acetate ( 1 r)

Compound 9 (Y.rog, \&.lommol), compound 7 $(\cdot \vee \vee g, \varepsilon .10 \mathrm{mmol})$, zinc dust $(\leqslant \mathrm{mg})$, glacial acetic acid $(\cdot \varepsilon \mathrm{ml}, \vee \mathrm{mmol})$ and dioxan ( $\left.{ }^{\circ} \circ \mathrm{ml}\right)$ 
were placed in flask, equipped with reflux condenser, boiling stones were added. The reaction mixture was refluxed gently for $q$. minutes, and then worked up as prescribed in section $r$.r to liberate $r(\cdot .0 r \mathrm{~g}$, $r$ r\% yield $)$ as white crystals. m.p. $\left.110_{-}\right) \wedge 7^{\circ} \mathrm{C} . \mathrm{R}_{\mathrm{f}}=\cdot \wedge$. IRcm rrre\&19. (N-H) of secondary amide \&sulfonamide, ror $(\mathrm{C}=\mathrm{O})$ of acetate ester, I TAV $(\mathrm{C}=\mathrm{O})$ of secondary amide, lo9r, lorV \&

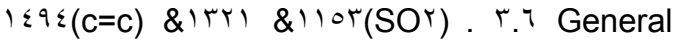
procedure to liberate the final compounds ( $1 \mathrm{r}$, $1 \leqslant \& 10)^{(r r)}$

Ester compounds $(1 \cdot, \mid r, 1)$, each ( $(\cdot \mathrm{rg}$, r.. $\mathrm{mmol}$ ) was dissolved in a minimum volume of ethanol $99 \%$ : THF (r:1) mixture. The solution was cooled to $1 \wedge{ }^{\circ} \mathrm{C}$, and then sodium hydroxide ( $r \mathrm{~N}, 1 . T \mathrm{ml}, r . r \mathrm{rmmol})$ was added drop wise with continuous stirring over a period of $r$. minutes. Stirring was continued at $11^{\circ} \mathrm{C}$ for additional three hours. The reaction mixture was acidified with $\mathrm{HCl}(r \mathrm{~N}, 1 . \vee \mathrm{ml}$, $r$. $\{$ mmol), excess of cold water was added and the precipitate was filtered and dried to give the final compound( $1 r, 1 \leqslant$ or 10$){ }^{r r}$

Compound $1 \mathrm{r}$ : (09\% yield) as white crystals. m.p. ror-ro ${ }^{\circ} \mathrm{C}$. $\mathrm{R}_{\mathrm{f}}=\cdot$. 9 r. IR rro9 $(\mathrm{O}-\mathrm{H})$ of $\mathrm{H}$ bonded phenol, rrV $\{(\mathrm{N}-\mathrm{H})$ of secondary amide, rirr $(\mathrm{N}-\mathrm{H})$ of amine salt, $177 r(\mathrm{C}=\mathrm{O})$ of secondary amide, lo9r, loor \& $1 \leqslant 9$ (Aromatic) \& 1 rr \& \& 1100 (SOr) $\mathrm{cm}^{-1}$.CHN

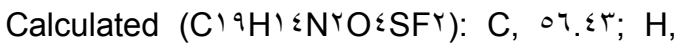
r.ะ१; N, ч.qт. Found: $C$, or.qr; $H, r .1) ; N$, T.Or.

Compound $1 \leqslant$ : ( $\circ \vee \%$ yield) as white crystals. m.p. $19 .-19 r^{\circ} \mathrm{C}$. $\mathrm{R}_{\mathrm{f}}=.99$. IR rrr $(\mathrm{O}-\mathrm{H})$ of $\mathrm{H}$ bonded phenol, $\mathrm{r} 19 .(\mathrm{N}-\mathrm{H})$ of secondary sulfonamide, $1710(\mathrm{C}=\mathrm{O})$ of secondary amide,

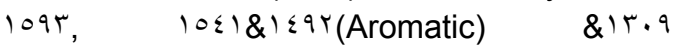
\&llor(SOr) $\mathrm{cm}^{-1}$.CHN Calculated (Cr.HITNYOSSFr): C, OV.\&); H, r.AT; N, r.V.

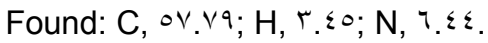

Compound $10:(00 \%$ yield) as a faint yellow crystals. m.p. $199-r \cdot{ }^{\circ} \mathrm{C} . \mathrm{R}_{\mathrm{f}}=\cdot$. Ar. IR rrr $(\mathrm{O}-\mathrm{H})$ of $\mathrm{H}$-bonded phenol, $\mathrm{rr} \cdot \mathrm{l}(\mathrm{N}-\mathrm{H})$ of secondary sulfonamide, $\quad 17 \wedge \wedge(\mathrm{C}=\mathrm{O})$ of secondary amide, 1097, 10ะ.\&1 190 (Aromatic) \& 1 -11 \& $110 \mathrm{r}(\mathrm{SOr}) \mathrm{cm}^{-1}$.CHN Calculated (Cr)HITNROOSFr): C, 07.V0; H, r.r.; N, r.r. Found: C, 07.0V; H, r.VO; N, T.r.

\section{Pharmacology}

$\underline{r . . \wedge \text { Mosul College of Pharmacy }}$
Albino rats of either sex weighing $(10, \pm 1$. $\mathrm{gm}$ ) were supplied by the National Center for Quality Control and Drug Research and were housed in the animal house of the College of Pharmacy, University of Baghdad under standardized conditions (Ir light-ir dark cycle) for $\checkmark$ days for acclimatization. Animals were fed commercial chaw and had free access to water ad libitum. Animals were brought 1 hour before the experiment to the laboratory, and were divided into five groups (each group consist of 7 rats) as follow: group A: served as control and treated with the vehicle (propylene glycol $0 . \% \mathrm{v} / \mathrm{v}$ in water); group B: treated with sodium diclofenac (reference agent) in a dose of $\mathrm{rmg} / \mathrm{kg}$ suspended in propylene glycol $0 . \% \mathrm{v} / \mathrm{v}$ in water ${ }^{(r \xi)}$; group $\mathrm{C}, \mathrm{D}$ and $\mathrm{E}$ : treated with tested compounds $1 T, 1 \leqslant$ and 10 respectively in a dose equivalent to $0 . \mathrm{mg} / \mathrm{kg}$ of diflunisal as finely homogenized suspension in $0 . \% \mathrm{v} / \mathrm{v}$ propylene glycol in water (The doses were chosen as being equivalent to $1 r^{\circ}, r_{0}, 0$. and $1 \cdots \mathrm{mg} / \mathrm{kg}$ diflunisal. According to preliminary results the decision was made to choose the dose that equivalent to $0 . \mathrm{mg} / \mathrm{kg}$ diflunisal).

\section{Anti-inflammatory activity}

The anti-inflammatory activity of the tested compounds was studied using egg-white induced edema model.. ${ }^{\text {to }}$ Acute inflammation was induced by a subcutaneous injection of $\because .0 \mathrm{ml}$ of undiluted egg- white into the planter side of the left hind paw of the rats; 10 minutes after i.p. administration of the drugs or their vehicle. The paw thickness was measured by vernier at eight time intervals $(\cdot$, $10, r \cdot, r \cdot, r \cdot, 1 \wedge \cdot, r \varepsilon \cdot$ and $r \cdot \cdot$ minutes) after vehicle or drug administration.

The data are expressed as mean \pm S.E.M. and results were analyzed for statistical significance using Student t-test (Two-Sample Assuming Equal Variances) for comparisons between mean values. While comparisons between different groups were made using ANOVA: Two-Factor Without Replication. Probability $(P)$ value of less than. .0 was considered significant.

\section{Results and discussion}

The most widely used primary test to screen new anti-inflammatory agents is based on the 
Irq J Pharm

Vol. v\&^. Nol. ץ..^

ability of a compound to reduce local edema induced in the rat paw following injection of an irritant agent. $^{r r}$ When egg-white is injected into the paw of rats, a substantial induction of COX- $r$ is observed at $r$ hours

coinciding with enhanced $P G s$ and local edema ${ }^{(r)}$. Tables $1 \& r$ show the effect of tested compounds on egg-white induced edema as an indicator for their antiinflammatory activity. The intraplanter injection of egg-white into rat hind paw induces a progressive edema, which was reached maximum (measured by millimeter) after $r$ hours of injection.
Table 1 showed the effect of tested compounds $(1 T, 1 \leq \& 10)$ in respect to control group. All tested compounds were effectively limited the increase in paw edema, with the effect of compounds $1 r$ \& I s started at time $r$. minute (significantly different compared to control), while compound 10 started at time $1 r$. minute, which mean it has later onset of action than the other tested compounds. However, the effect of all tested compounds continued till the end of the experiment with statistically significant $(P>\cdot .0)$ reduction in paw edema. At time $r .$. minute compounds I $\varepsilon, 10$ significantly different compared to 1 .

Table 1: Effect of Control,Diclofenac \& Compounds $1 \%, 1 \leq \& 10$ on egg-white induced paw edema in rats.

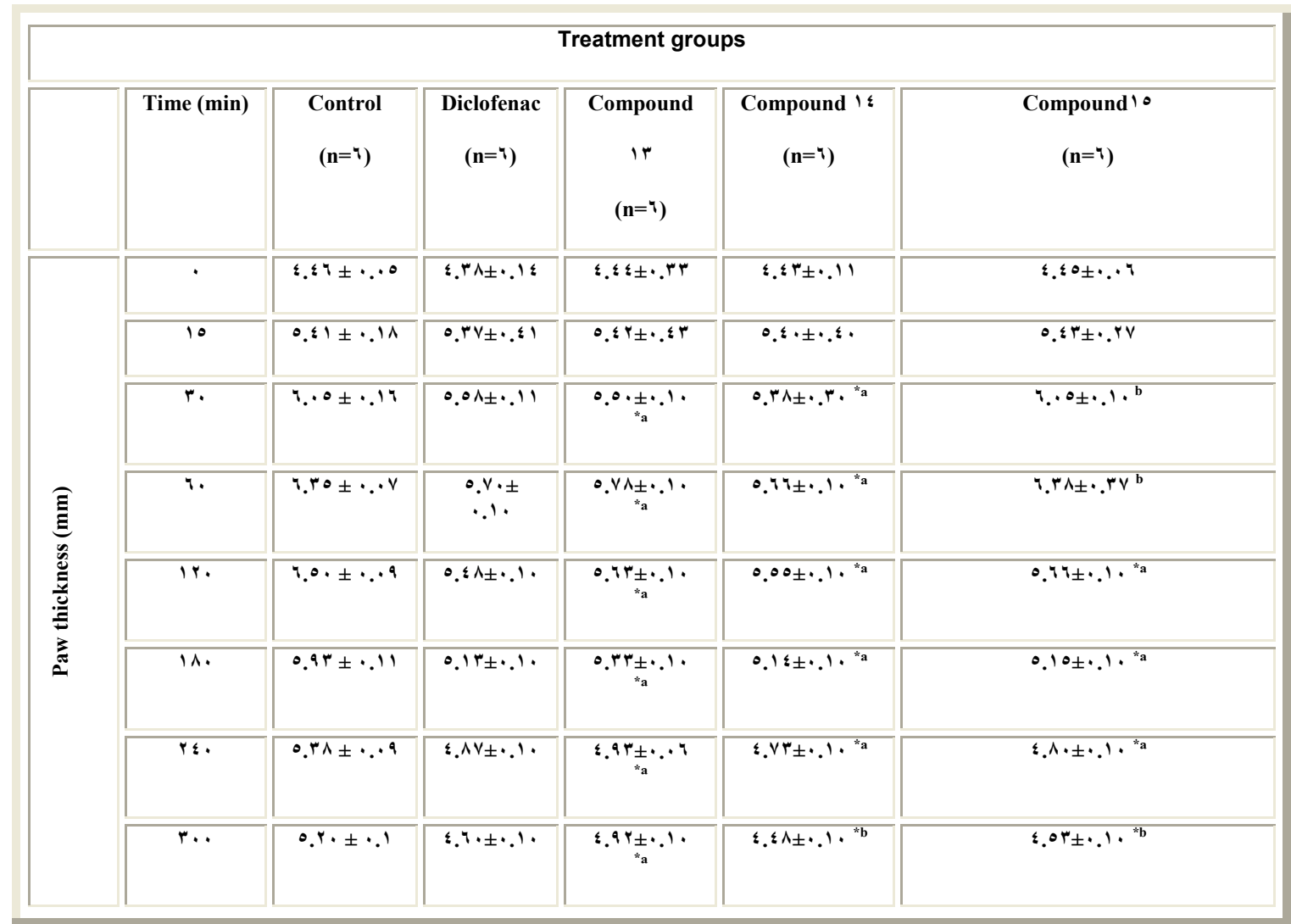

Non-identical superscripts ( $\mathrm{a}, \& \mathrm{~b})$ among different tested compounds are considered significantly different $(P<\cdot . \cdot 0)$

* Significantly different compared to control $(P<\cdot .0)$.

Table 1 showed the effect of tested compounds $(1 \mathrm{~T}, \quad 1 \leq \& 10)$ in respect to reference group (diclofenac). As seen in this table; at time - and 10 minute there are no differences among different groups; at time $r$. and $T$. compound 10 is significantly lower effect than diclofenac, compound $1 r$, and compound I $\varepsilon$. 
However, it appears that all the tested compounds had a comparable effect to that of diclofenac at times of $1 r_{\cdot-r . .}$ minute of experiment except compound ir which showed statistically significant $(P>\cdot .0)$ lower effect than other tested compounds ( $1 \leqslant, 10$ \& diclofenac) at time $r .$. minute.

\section{Conclusion}

In vivo anti-inflammatory study showed that the incorporation of - $_{-}$ aminobenzenesulfonamide, $\quad$-amino-Nmethylbenzenesulfonamide, or $\mathrm{N}-(\varepsilon-$ aminophenylsulfonyl)acetamide into well known anti-inflammatory drug (diflunisal) potentially increase its anti-inflammatory activity since diclofenac more potent than other NSAIDs ${ }^{(r q)}$.

Finally compound it showed lower effect comparing with compound $1 \leqslant$ and 10 and that $\mathrm{CH}_{r}$ and $\mathrm{COCH}_{r}$ may play important roles in reduction of paw thickness.

\section{Acknowledgments}

We are grateful to the staff members and Colleagues of the Department of Pharmaceutical Chemistry and the Department of Pharmacology and Toxicology .Also we wish to express grateful thanks to M.Sc. Sabah Jawad for his help and support.

\section{References}

1. Vane JR. Inhibition of $p G$ synthesis as mechanism of action for the aspirin-like drugs. Nature 19V1; rrI - rrr.

r. Laurance, D.R.; Bennett, P.N. and Brown, M.J.,: Clinical pharmacology ( ${ }^{\text {th }}$ Ed.). Churchill Livingstone, London; r..r,. r^.

r. Marnett LJ; Rowlinson SW; Goodwin DC; Kalgutkar AS, Lanzo CA.: Arachidonic acid oxygenation by COX-1 and COX-r. Mechanisms of catalysis and inhibition. J. Biol. Chem. 1999, rvะ: rrq.r-rrq. .

£. Chandrasekharan NV, Dai H,. Roos KL. Evanson N.K.; et al. : Cox-r, a COX-1 variant inhibited by acetaminophen and other analgesic antipyretic drugs. Proc. Natl. Acad. Sci. USA; r..;q9:1rqr т. 1rqu.
•. Dinchuk J.E, Lui RQ, Trzaskos JM.. COX-r: in the wrong frame in mind. Immunol. Lett. r..r;^r:Ir!.

7. Katzung BG.. (Ed.): Basic and clinical pharmacology, ( ${ }^{\text {th }}$ Ed.). McGraw-Hill,

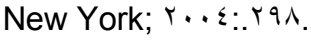

v. Hardman J.G, Limbird LE, Molinoff PB. Goodman and Gilman's The Pharmacological Basis of Therapeutics (1. th ed.), McGraw-Hill, New York,. Y.. l: หง.

^. Lipsky PE; Abramson SB; Breedveld, FC; et al..: Analysis of the effect of COX-r specific inhibitors and recommendations for their user in clinical practice. J. Rheumatol. r...;rv: $1 r r \Lambda_{-}-1 r \varepsilon \cdot$.

१. Jones C. Practical COX-1 and COX-r pharmacology: What's it all about? । 999

1. Mc Adam BF; Catella-Lawson F; Mardini $I A$,. et al. Systemic biosynthesis of prostacyclin by COX-Y. Proc. Natl. Acad. Sci. USA 1997; ( $)$ : rVY.

11. Vane J. Towards a better aspirin. Nature 199ะ;rчV: r10.

ir. Hannah J; Ruyle W.V; Jones H; et al.: Novel analgesic-anti-inflammatory salicylates. J. Med. Chem. (9v৯;r): 1.9r.

ir. Van J. Botting J..: Selective COX-Y inhibitors. Pharmacology, clinical effects and therapeutic potential. Kluwer Academic publishers, Dordrecht; 199^; . 19-r.

Iะ. Talley JJ. ;Brown DL.; Carter, J. S.; Graneto, M. J.; et al. J. Med. Chem.

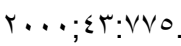

10. Penning, T.D.; Talley, J.J.; Bertenshaw, S.R.; et al $199 \vee$.: Synthesis and biological evaluation of the 1, - -diarylpyrazole class of cyclooxygenase-r inhibitors. J. Med. Chem.; $\{:: 1 r \leqslant v$.

17. Lages A.S; Silva K.C.M; Miranda A.L.P; et al.. Synthesis and pharmacological evaluation of new flosulide analogues, synthesized from natural safrole. Bioorg. Chem. Lett.; 199^: ^: 1^r.

iv. Zarghi, A.; Rao, P.N.P. and Knaus, E.E.: Sulfonamido, azidosulfonyl and $\mathrm{N}$ acetylsulfonamido analogues of roficoxib: 
is a potent and selective COX- $r$ inhibitor. Bioorg. Med. Chem. Lett. $r \cdot \varepsilon_{;} ; \varepsilon_{: 190 \mathrm{~V}}$.

1^. Furniss B.S.; Hannaford A.J; et al.. Vogel's textbook of practical organic chemistry ( $0^{\text {th }}$ Ed.). Longman, London

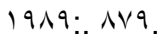

19. Furniss B.S.; Hannaford A.J; et al. Vogel's textbook of practical organic chemistry ( $0^{\text {th }} \mathrm{Ed}$.). Longman, London; 1919:..791.

r. Pardip K.; Jee B. Amidon G.L.: J. Pharm. Sci.; 1911; $\vee \cdot: 1 r 99$.

r. Furniss BS; Hannaford AJ; et al. Vogel's textbook of practical organic chemistry ( $0^{\text {th }}$ Ed.). Longman, London 1919 :. 917.

r.. Hongchen Q.; Rao PNP, Knaus EE.: Design, synthesis, and biological evaluation of $\mathrm{N}$-acetyl-r-carboxybenzene sulfonamides. Bioorg. Med. Chem r...o; $1 r: r \leq 09-r \leq 7$.

rr. Bodansky M, Klausner YS. Ondetti MA, Peptide synthesis ( $r^{\text {nd }}$ ed.) John Wiley and Sons, New York. I $9 \vee 7$.

rะ. Chandrashekhar SP; Naveen KJ; Amarjit, $S$, Shinivas, KK.: Modulatory effect of
COX inhibitors on sildenafil-induced antinociception. Pharmacology r..r;

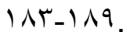

ro. Vogel HG, Goethe JH,: Drug discovery and evaluation. Pharmacological assay ( $r^{\text {nd }}$ Ed.). Springer-Verlag, Berlin Heidelbers; r... r.. vol.

r.. Winter CA; Risley EA., Nuss G.W: Carrageenan-induced edema in hind paws of the rat as an assay for antiinflammatory drugs. Proc. Soc. Exp. Bio. Med. 197r: 111: 0 $\leqslant \leqslant-0 \leqslant V$.

rv. Seibert K, Zhang Y, Leahy K,. Masferrer J.; et al.: Pharmacological and biochemical demonstration of the role of cyclooxygenase-r in inflammation and pain. Proc. Natl. Acad. Sci. USA; 199ะ: q): $14.1 \%$.

ץ^. Reitz DB. and Isakson PC.: Curr. Pharm. Design; 19901: r।1.

rq. Harvey R.A. Champe, P.C: Lippincott's illustrated reviews pharmacology ( $r^{\mathrm{rd}} \mathrm{Ed}$.) . r. . $7 ; 0 . r$. 